\title{
Türk Çocuklarının Ses Gelişim Özellikleri ve İlk Okuma Yazma Öğrenme
}

\author{
Ali Osman ÖZCAN ${ }^{*}$ ve Aysel Ferah ÖZCAN**
}

$\ddot{0} z$

Bu makalede sese dayalı olarak Türkçe öğretebilmek için ihtiyaç duyulan araştırma konuları ele alınmıştır. Türkçe seslerin çıkış özellikleri, çocuklarda Türkçe seslerin gelişimi ve bunların edinimleri konusundaki araştırmaları dikkate almadan Türkçe ilk okuma yazma öğretimini sese dayalı olarak doğru bir şekilde yapabilmek pek mümkün değildir. Türkçe seslerin zihinde işlenişleri konusunun gerekliliğine de değinilerek Türkçe ilk okuma yazma gerçekliğinin ses alanı derinlemesine değerlendirilmiștir.

Anahtar Sözcükler: Türkçe İlk Okuma Yazma, Sesbilim, Dil Edinimi, Zihinsel İşlemler, Ses Algısı, Ses Farkındalı̆ğ

\section{Sound Developmental Characteristics of Turkish Children and Literacy Learning}

\begin{abstract}
In this paper, research topics that are necessary for sound-based Turkish teaching are addressed. It is impossible to properly carry out a sound-based literacy instruction in Turkish without paying particular attention to the articulation characteristics of the sounds and the research regarding the sound development and phonetic acquisition in Turkish. The sound field of literacy acquisition phenomenon in Turkish is thoroughly studied in this article by mentioning the significance of cognitive processing of Turkish sounds.
\end{abstract}

Keywords: Literacy Acquisition in Turkish, Phonology, Language Acquisition, Cognitive Processes, Sound Recognition, Sound Awareness

\footnotetext{
* Prof. Dr., İstanbul Gelişim Üniversitesi İktisadi İdari ve Sosyal Bilimler Fakültesi Psikoloji Bölümü. E-posta: aliosmanozcan@yahoo.com

${ }^{* *}$ Okt., Sakarya Üniversitesi Eğitim Fakültesi. E-posta: ayselferah@yahoo.com
} 
Sayfa/Page | 68

\section{Giriş}

Çocukların ses alanına ait bilgi sistemlerini oluşturmalarında Türkçedeki seslerin kullanım sıklıklarının ve bu seslerin söyleniş ve söyleyiş özellikleriyle ilk kavranılan seslerin hangileri olduğunun ve daha sonraki sıralanışlarının bilinmesi, Türkçe ilk okuma yazma öğretiminin temellendirilmesinde önemli bir işleve sahiptir. Bu öğretim Türkçe ses ve harflerin öğretim sıralarına göre şekillendirilir. "Sesten hareket eden bir ilk okuma yazma öğretimi sadece harflerin yazım kolaylığını (görsel ve sanatsal yazı) değil; ses-sözcük sıklıkları, çocuklarda seslerin gelişimi, seslerin çıkarılış kolaylığı ve benzeri hususları da dikkate almalıdır"1. Hangi yöntemle öğretilirse öğretilsin, Türkçe seslerin çocuklardaki gelişim sıralarının ve harflerin yazım kolaylıklarının bilinmesi ilk okuma yazma öğretiminde yol gösterici olabilir.

Çocukların büyük çoğunluğu ilk okuma yazma öğrenmeye başladıklarında ses çözümlemesini yapabilecek olgunluktadırlar. Buna rağmen bazı çocukların sesbilgisel farkındalığının düşük olduğu da araştırmalarda vurgulanmaktadır. Okuma güçlüğü olan çocuklarda sesbilgisel farkındalık daha geç gelişmektedir. İlk okuma yazma öğrenmenin başlangıcında sesin daha ileri kullanımını gerektiren parçalarüstü bürünleri uygulamakta ve kelimeler içinde seslerin ayırt edilmesinde çocukların daha fazla zorlanacakları da bir gerçektir. Türk çocuklarında hangi seslerin daha önce kazanıldığı ve seslerin öğrenilmesinde hangi aşamalarda çocukların zorlandıkları ile ilgili 6-12 yaş dönemlerini kapsayan araştırmalar da fazla değildir. İlk okuma ve yazma eylemleri düzenlenirken sesbirimlerin sözcük konumlarına göre işlenmesine özen gösterildiğinde, ilk okuma yazma çocuklar için daha kolay ve eğlenceli bir eyleme dönüşecektir.

İlk okuma yazma öğretiminde, çocukların aşağıda sıralanan türden kazanımları edinmeleri beklenir:

Ses alanını keşfetme, sesleri ayırt edip doğru çıkarabilme, Seslerin özdeşlik, benzerlik ve farklılıkla ilgili renklerini, tonlarını vb. ayırt edebilmeye ilgi duyma.

Kalem-kâğıt, yazı- resim ve işaret kavramlarını ayırt edebilme.

${ }^{1}$ Aysel Ferah, "2005 Türkçe Öğretim Programı ve Ses Temelli Cümle Yönteminin Ses Sıklı̆̆ı ve Hece Oluşturma Açısından İncelenmesi", Çăgdaş Ĕğitim Dergisi, 2011, 36, (383), s.40. 
Alfabedeki harflerin sesleri yansıttığını kavrayabilme; harflerin dışındaki nokta, virgül, ünlem gibi işaretler hakkında bilgi ve beceri kazanma; resim-yazı özdeşliğini ve benzerliğini birbirinden ayırt etme.

Hece ve cümleleri olușturan ses işaretlerinin soldan sağa doğru yazıldıklarını, satırlar üzerine yazılmaları gerektiğini ve bunların biçimlenişlerini asıllarına özgü kuralları olduğunu kavrama.

Seslerden hece, kelime ve cümle bütünleri oluştuğunu fark etme ve bu bütünleri seslere ayırabilme.

Sözcük başı, ortası ve sonunda da olsa sesin aynı ses olduğu gerçeğinin değişmezliğini kavrama.

Cümle başı, ortasl, sonunda yer alan seslerin ortografik özelliklerinin sira, seri ve gruplarını ayırt etme.

\section{Alfabe birimlerinin anlam bağlamlarını kavrama.}

Çocuğun seslerin işaretlerini sıraya koyma, düzenleme, birleştirme, ayırma ve kendi aralarındaki ilişkileri kurarken ortaya koyduğu yapılar, onun zihin ile ilgili işlemlerini yansıtır. İlk okuma-yazmayı öğrenirken alfabeyi oluşturan işaretler arası ilişkileri kurup harflerin-seslerin işlevleriyle zihin ile ilgili işlemlerini doğru bir şekilde yapmak zorundadır. Zihin kendi içinde harfler arasında karşılaștırma yaparak, ilk okuma yazmaya ait belirli ilişki kavramlarını elde eder. $\mathrm{Bu}$ karş̧laştırmayı yapabilme çocukların dildeki ilişki sözcüklerini kavrayışlarıyla da (edatlar, bağlaçlar) ilişkilidir. Bu etkinlik esnasında önce bir işareti diğerinin yanına getirir ve onu ortaya koyduktan sonra dikkatini diğerlerine yöneltir ve onlar arasında kendine göre bir ilintiyi belirler. İlk okuma ve yazma öğretiminde ses öğretiminde sesbilgisi ile ilgili işlemleme özellikleri göz ardı edilmemelidir.

İlk okuma yazma etkinliği; Türk alfabesindeki harflerin birbirleriyle ilişkilerini tanıyarak, harflerin bağlı bulunduğu dille ilgili birimleri yazı içinde ayırt ederek, yazılı metnin içeriğini kavrama olarak tanımlanabilir. Harfleri temel alarak içerikteki anlamı kavrayış etkinliği de ilk okuma anlamına gelir. Harflere dayalı olarak yapılan eylemlere ve bunların dilbilim değerlerini kavrama etkinliğine de ilk okuma diyebiliriz. Okutma; öğrencileri okuma eylemine yönlendirmek, dil birimlerinin yazıya dökülen biçimlerinin içeriklerini çözümletmek olarak tanımlanabilir. Bilgi işlem yaklaşımına göre okuma; çocuğun zihnine dilin sözlü birimlerinin yazıya dökülmüş biçimlerini sunarak çocuğa zihin ile ilgili işlemler yaptırma etkinliğidir.

Sayfa/Page | 69

İGÜSBD

Cilt: 1 Sayı: 2

Ekim /

October 2014 
Sayfa/Page | 70

Yazma; sözleri ve düşünceleri alfabenin harfleriyle ifade edebilmek; yani yazıya aktararak anlatmak olarak tanımlanabilir. Çocuklar, Türk alfabesindeki işaret ve harfleri yazıya dökerek yazı içinde anlatabildiklerinde yazma becerisini kazanmış olurlar. Türk alfabesi, Türkçenin yazı sistemini ifade eder. Yazılı bir şeyi okuyamama durumuna "Yazıyı sökememe" denir. Yazı, sözlerin çizgilerle gösterilme ve anlamlandırılma sistemidir. Harfler, sözlerin yazı işaretleriyle eşdeğerlilik ilişkisi kurulduğunda; yani zihinde simgeler oluşturduklarında okumanın temelini oluştururlar. Bu bakımdan ilk okuma yazma öğretiminde, harflerin öğretim sırası önem taşır. Bu makalede Türk çocuklarının ses gelişim özellikleri ve bunların ilk okuma yazma öğretimindeki yansımaları ele alınmaya çalışılmıştır.

\section{Türk Çocuklarının Ses Gelişimi Özellikleri ve İlk Okuma Yazma}

Çocuklarda ses gelişimi denilince ilk olarak sese karşı duyarlılık (algılama, tanıma, hatırlama), seslerin boğumlanması ve seslerin parçalar üstü bürünlerinin konuşmada doğru kullanılması akla gelmektedir. "Ses algısında; seslerin gruplanmaları, tam alglanmayan seslerin tamamlanması, seslerin sürekliliği, yakınlık ve benzerlik ilişkileri, seslerin iyi bir şekilde gruplanması gibi algısal düzenlemeleri yapabilen çocuklar, ilk okuma-yazma öğrenmede başarılı olurlar "2. Sesler, belirli bir düzenle bir araya gelerek anlamlı yapılara dönüşmektedirler. Ses gelişimi ile ilgili yapılan araștırmalar "Çocukların sesi ayırt etmeleri-tanımaları-edinmeleri" sorununa odaklanmıştır. Seslerin boğumlanması ve söyleyiş özellikleri konusunda da bazı araştırmaların yapıldığı dikkati çekmektedir. Ancak Türkçe seslerin boğumlanmaları ile ilgili araştırmacılar arasında görüş birliği olmadığı gibi ünlü ve ünsüz sayısı konusunda da görüş birliği bulunmamaktadır. Araştırmacıların Türkçe sesler alanına yaklaşımlarında da görüş ayrılıkları söz konusu olduğu görülmektedir.

"Fizyolojik bilişsel ve sosyal olarak genel gelişim sürecinde sesbilgisi edinimi çocuğun üstesinden gelmesi gerektiği önemli süreci içermektedir. Birincisi, anadilin anlam ayırıcı özellikli sesbirimlerini ve bunların anlam aktarma (karşıtlık) işlevlerini ayırt edebilme ve üretebilme sürecidir. $\mathrm{Bu}$ süreçte algısal olarak, çocuğun karşıtlık işlevi içinde bulunan parçasal birimleri ve parçalarüstü birimleri akustik parametrelerine göre ayrıştırması, kümeleyebilmesi gerekmektedir. Üretimsel olarak ise, çocuk söz zinciri içinde sesbilgisel karşıtlıkları gerçekleştirebilmek için gerekli sesletim parametrelerini otomatik olarak kontrol edebilmeyi öğrenmek durumundadır. $\mathrm{Bu}$ süreçle bağdaşık olarak çocuğun aynı zamanda

${ }^{2}$ Aysel Ferah, "illk Okuma-Yazmada Ses Algısı", Çăgdaş Eğitim Dergisi, 2001, 280, s. 27. 
üstesinden gelmesi gerektiği ikinci sorun, edinmekte olduğu sesbilgisel karşıtlıkları dilinin kurallarına göre örgütleyebilme ve kullanabilmedir. Başka deyişle çocuk, dilinin dizimsel yapısını oluşturan sesbirim dizge bilgisini de edinmek durumundadır"3.

Sese karşı duyarlılık, seslerin doğru boğumlanması, ayırt edilmesi ve parçalarüstü bürünlerin konuşmada kullanılması aşamalı olarak gelişen becerilerdir. Çocukların sözcüklerin seslerden ve hecelerden oluştuğunu fark etmelerinin yaşa bağlı olarak geliştiği araștırmalarla ortaya konulmuştur. Çocuklar, önce sözcüklerin hecelere ayrılabildiğini sonra hecelerin seslerden oluştuğunu yaşa bağlı olarak kavramaktadırlar. Yani bütünden parçaya doğru bir gelişimden söz edilmektedir. Aslında burada parça-bütün, bütün-parça arası ilişkileri belirleyebilmek de tam olarak olası gözükmemektedir. Ancak sözcükleri seslerine ayırmak küçük çocuklar için oldukça zor bir eylemdir.

"Haskell ve Barrett (1989) çocuklarda ses farkındalığı ile ilgili şu görüşleri ileri sürmektedirler: Çocuklar genellikle söylenen hecelerin sesbirimlerden oluştuğunu anlayamazlar. Farkındalığın daha genel olan bu seviyesinde çocuklar birbiri ile uyaklı olan iki sözcüğü tanımayı veya bir diğerinden daha uzun olan sözcüğü bulmayı anlayabilirler. Bununla birlikte sesbirimleri sınıflandırma ve izole etme gibi daha hassas beceriler beş yaşından önce nadiren görülmektedir ve yazı yazmanın kazanımından önce ortaya çıkmamaktadır"4. Bu durum sözcüklerin seslerden oluştuğu olgusunu, zihinsel gelişime paralel olarak, çocukların ancak beş yaşlarında kavramaya başladığını göstermektedir. Bu yaşlarda ninni ve tekerlemelerin çocuklar tarafından sevilmesinin altında da herhalde bu ses tekrarlarının olması yatmaktadır, denilebilir. Bu gelişim yazılı dilde ilk okuma yazma öğrenme sürecinde de devam etmektedir.

Dilin ediniminde evrensel özellikler görülmekle birlikte nitelikleri bakımından kültürel etkilerin baskınlığından da söz edilmektedir. $\mathrm{Bu}$ bakımdan seslerin edinimi ile ilgili çalışmalar millî dilin kendine has yapısı üzerine odaklanarak yapıldığında; öğretimiyle ilgili daha bilimsel sonuçlar elde etmek de mümkün olacaktır. Durgunoğlu ve Öney $(2000)^{5}$ yaptıkları

\footnotetext{
3 Seyhun Topbaş, "Konuşma Sorunlarında Sesbilgisel Yaklașım", Anadolu Üniversitesi Eğitim Fakültesi Dergisi, 1992, 5(1-2), s. 132.

${ }^{4}$ Gözde Gül, Hafif Derecede Zihinsel Engelli Çocukların Okuma Becerilerine Ses Bilgisel Farkındalık Becerileri Eğitiminin Etkisinin İncelenmesi, Basılmamış Yüksek Lisans Tezi, Hacettepe Üniversitesi Sağlık Bilimleri Enstitüsü Özel Eğitim Bilim Dal, Ankara, 2006.

${ }^{5}$ Aydın Durgunoğlu ve Banu Öney, "Literacy development in two languages: cognitive and sociocultural dimensions of cross-language transfer", In Editör
}

Sayfa/Page | 71

İGÜSBD

Cilt: 1 Sayı: 2

Ekim /

October 2014 
Sayfa/Page | 72

İGÜSBD

Cilt: 1 Sayı: 2 Ekim /

October 2014

araştırmada Türk çocuklarının fonolojik duyarlılık becerilerinin İngilizce konuşan çocuklara göre okumayı öğrenmede daha etkili olduğunu ortaya koymuşlardır. Türkçenin yapısından dolayı okuma-yazmaya daha çabuk ve kolay geçildiğini ifade etmişlerdir. Dolayısıyla Türkçe ilk okuma yazma öğretiminde de Türkçenin edinimine dayalı araştırma sonuçlarından istifade edilerek uygulamaların yapılması dilimizi doğru, kurallı ve etkili öğretebilmek bakımından gereklidir.

Çocukların sesleri edinimi ile ilgili araştırmalarda Türk çocuklarının erken edindikleri ses birimleri belirlenmiştir. Kündük (1990), yaptığı bir araştırmada 2;6 ile 3;6 yaşları arasındaki Türk çocuklarının /k, t, d, m/ sesbirimlerini diğerlerinden daha erken kazandıkları; Türk dilinin bazı özelliklerinin sesbirimlerin edinimini kolaylaştırabileceği sonucuna ulaşmıştır'. Görüldüğü üzere "k, t, d ve m" sesleri Türkçenin yapısına bağlı olarak erken dönemlerde edinilen seslerdir. Türkçe seslerin kullanım sıklıklarına dayalı araştırmalarda da " $k, t, d$ ve $m^{\prime \prime}{ }^{7}$ seslerinin en sık kullanılan seslerin başında geldiği anlaşılmaktadır. Ses sıklığı ve erken edinilen sesler arasında paralellik olduğu dikkati çekmektedir. Çocuklar bu sesleri küçük yaşlarda edinmektedirler. Ancak bu seslerin Türkçenin ses değerlerine uygun olarak çıkarılıp çıkarılmadı̆̆ı da araștırılmış değildir.

Topbaş (2006) 2-8 yaşları arasındaki çocuklar üzerinde yaptığı araştırmada erken edinilen sesbirimleri şöyle sıralamaktadır: "Genizsi sesler> patlamalı-durak sesleri> akıcı daralmalı yan daralmalı durak sürtünmeli> sürtünmeli> tek vuruşlu/. Genel olarak ötümlü sesler sözcük başı, ötümsüz sesler sözcük sonu konumunda daha erken edinilmekte ve sesbirimlerin ediniminde sözcük konumu belirleyici faktör olmaktadır "8. Uluslararası transkripsiyon alfabesinde genizsi sesler /m/, /n/; patlamalı durak sesleri /p/, /b/; daralmalı sesler /l/, /r/, /y/; sürtünmeli sesler /s/, /z/, /v/ ve /c/ olarak gösterilmektedir. $\mathrm{Bu}$ seslerin bazılarının gruplanmaları konusunda görüş birliği olmadığı da anlaşılmaktadır.

Sesin edinilmesinde hangi özelliklerin etkili olduğu da tartışma konusudur. "Hoşgör'ün (1991), 2;0 ve 3;0 yaşları arasındaki çocuklarla

Proceedings of the A Research Symposium on High Standards in Reading for Students From Diverse Language Groups, 2000, ss. 78-99.

${ }^{6}$ Seyhun Topbaş, Dil ve Konuşma Sorunlu Çocukların Sesbilgisel Çözümleme Yöntemi ile Değerlendirilmesi ve Konuşma Örüntülerindeki Sesbilgisel Özelliklerin Betimlenmesi, Basılmamıș Doktora Tezi, Anadolu Üniversitesi Sosyal Bilimler Enstitüsü, Eskişehir, 1994, s. 40.

${ }^{7}$ Canan Çimen vd., Şifrelerin Matematiği: Kriptografi, ODTÜ Yayıncılık, Ankara, 2008.

${ }^{8}$ Seyhun Topbaş, "Türkçe Sesletim-Sesbilgisi Testi: Geçerlilik-Güvenirlik ve Standardizasyon Çalışması", Türk Psikoloji Dergisi, 2006, 21(58), s.53. 
yaptığı bir araştırmada vurgu ve sözcük uzunluğu bitişik ünsüzlerin ediniminde etkili bir faktör olarak bulunmamış; ancak çocukların üç heceli sözcüklerinde daha fazla sesbilgisi ile ilgili işlem kullandığı gözlenmiștir. Yalnızca bitişik ünsüzlerin ediniminde incelenen işlemler hata sayısına göre şu şekilde sıralanmıştır: Akıcıların düşürülmesi, damaksılaşma, ötümlüleşme, benzeşim, önleştirme, akıcıların kayması, duraklaştırma, genizsilerin düşürülmesi, durak sürtünmeliye dönüşme, durak seslerinin düşürülmesi, ekleme "9. Dolayısıyla seslerin ediniminde hece veya kelime uzunluğu ile sesin yapısından kaynaklanan özelliklerin etkili olduğu anlaşılmaktadır. İlk okuma ve yazma öğretiminde de çocuk, sesleri hece, kelime ve cümleler içinde tanımak, ayırt etmek, birleştirmek ve kullanmak zorundadır. Sese duyarlılık kadar seslerin özelliklerine de duyarlılık ilk okuma yazma öğrenmek için gerekli bir beceridir.

Fonemlerin öğrenilmesi ile ilgili 2568 denek kullanılarak yapılan bir araştırmada erken edinilen ve geç edinilen sesler ile ilgili önemli sonuçlar elde edilmiştir. "Genizsilerin, patlamalı-kapantılı seslerin ve yarı ünlü/y/ sesinin pek çok dilde olduğu gibi erken edinilen sesler olduğu görülmüştür. Sürtünmeliler içinde /s/ ve /z/ seslerinin en zor sesler olduğu anlaşılmıştır. Artikülasyon yeri açısından da dudak seslerinin öncelikli olduğu, arkasından dişyuvasılların erken yaşlarda edinildiği gözlenmiştir. Türk çocukları altı yaşında da /r/ sesinin kazanımını tamamlamaktadırlar. Yedi yaşına basınca tüm sesler edinilmiştir... İki ünlü arası pozisyon edinilmiş ses dağarcığı açısından kısıtlı kalmaktadır. Erken edinilen seslerden dudaksıl patlamalı/kapantılı sesler iki ünlü arası pozisyonda iki yaş grubunda görülmemektedir.... Sonuçlar 'sözcük başı en kolay pozisyondur' varsayımını da haklı çıkarmamaktadır. /k/, /l/, /v/, /r/ ve /n/ sesleri örneklerinde olduğu gibi, bazı seslerin diğer pozisyonlarda sözcük başı pozisyondan daha erken kazanıldığı görülmektedir. Türk çocuklarının Türkçe ünsüzleri sözcük başı, iki ünlü arası ve sözcük sonu edinim yaş ve sıraları aşağıdaki tablo da gösterilmiştir " 10 :

${ }^{9}$ Topbaş, a.g.e., 1994 , s 45.

${ }^{10}$ Pınar Ege, "Türkçede Fonemlerin Edinimi", 2. Ulusal Dil ve Konuşma

Bozuklukları Kongresi Bildirileri, Kök Yayıncılık, Ankara, 2005, ss. 139-140.

Sayfa/Page | 73

İGÜSBD

Cilt: 1 Sayı: 2

Ekim /

October 2014 
Tablo 1. Türkçede Ünsüz Fonemlerin \%85 Kriterine Göre Edinilmesi

\begin{tabular}{|c|c|c|c|c|}
\hline & Yaş Grubu & Sözcük Başı & İki Ünlü Arası & Sözcük Sonu \\
\hline \multirow{5}{*}{$\begin{array}{r}\text { Sayfa/Page | } 74 \\
\text { IGÜSBD } \\
\text { Cilt: } 1 \text { Sayl: } 2 \\
\text { Ekim / } \\
\text { October } 2014\end{array}$} & 2 & $m, p, b, t, y$ & $\mathrm{~N}, \mathrm{t}, \mathrm{d}$ & $\mathrm{m}, \mathrm{n}, \mathrm{p}, \mathrm{t}, \mathrm{k}, \mathrm{v}, \mathrm{y}$ \\
\hline & 3 & $\begin{array}{l}d, k, g, f, v, s, n, c, c, \\
s ̧, h\end{array}$ & $\begin{array}{l}m, p, b, k, g, f, v, z, c ̧, c, \\
s ̧, y\end{array}$ & s, ç, ş, l \\
\hline & 4 & $\mathrm{Z}$ & $\mathrm{s}, \mathrm{l}$ & $f, r$ \\
\hline & 5 & $\mathrm{~L}$ & $\mathrm{H}$ & $\mathrm{z}, \mathrm{h}$ \\
\hline & 6 & $\mathrm{R}$ & $\mathrm{R}$ & \\
\hline
\end{tabular}

Tablo1 incelendiğinde; çocukların /b/, /t/, /m/, /p/ seslerini /s/, /z/, /l/, /k/, /r/ seslerinden önce edindikleri anlaşılmaktadır. Seslerin boğumlanma noktalarının edinilmelerinde etkili olduğu söylenebilir. Türkçe seslerin ediniminde sesin sözcükte geçtiği yerin de önemli olduğu anlaşılmaktadır. İlk okuma yazma öğrenmede sesin sözcüğün, cümlenin başında, ortasında ve sonundaki pozisyonlarının öğretilmesi sesin değişmezliğini kavramayı ve alfabetik bilgi (harf adı bilme) ile sesin eșleștirilmesini kolaylaştırıcı alıștırmalardır.

İlk okuma ve yazma açısından da seslerin başta-ortada ve sonda verildiği durumlardan hangisinde daha kolay öğrenildiği konusu da araştırılmaya değer bir konudur. Öztunç (1994) ${ }^{11}$ tarafından yapılan bir araştırmada da altı yaşlarındaki çocukların büyük-küçük harf karşılıkları hakkındaki bilgiyi karıștırdıkları; kelime kavramı ile ilk ve son harf kavramlarında zorlandıkları; harf ve kelime kavramlarını birbirine karıştırdıkları tespit edilmiştir. Bu kavramlar yazı öğrenildikten sonra gelişmektedir. Küçük yaştaki çocuklar ilk ve son gibi kavramları anlamakta zorlandıklarından ilk veya son ses kavramını da anlamlandırmakta zorlanmaktadırlar. İlk okuma yazmaya hazırlık döneminde çocuklarda harf-ses-kelime kavramlarının henüz tam gelişmediği bir gerçektir.

${ }^{11}$ Selda Öztunç, Okuma Kavramları Testinin Türk Çocuklarına Uyarlanması, Basılmamış Yüksek Lisans Tezi, Marmara Üniversitesi Sosyal Bilimler Enstitüsü Sınıf Öğretmenliği Ana Bilim Dalı, İstanbul, 1994. 
"Okuma yazma öğrenmek için seslerin farkındalığının yeterli olmadığı harfleri adlandırmayla da ilişkili olduğu belirtilmektedir"12. Türkiye'de de benzer araştırmalar yapılmıştır. Örneğin Karakelle (2004)13 okuma hızı üzerinde, öğretim yılı başında harf isimleri bilmenin ve sözcüklerin ses-söyleyiş özelliklerinin farkında olmanın etkili olduğu sonucuna ulaşmıştır.

Acarlar ve ark. (2002) yaptıkları bir araștırmada 3-8 yaşları arasındaki 65 çocuk üzerinde üst dil becerilerinin gelişimi ve okuma ilişkisini araştırmışlardır. "Sonuçta 3-8 yaşları arasındaki anadili Türkçe olan çocukların üstdil becerilerinin yaşlara göre gelişiminin diğer dillerle benzer bir seyir izlediği görülmüştür. Sözcügü hecelere bölme 3 yaşından itibaren yapılabilmesi nedeniyle en kolay işlem olup cümleyi sözcüklere bölme de 3 yaşından itibaren hızla gelişmekte olan ve sözcükleri tanıma okumadan bağımsız olarak ortaya çıkan ancak okumadan olumlu etkilenen bir beceridir. Sözcüğü seslerine ayırma ve verilen sesin sonda olduğu sözcükler bulma işlemlerinde okul öncesi dönemde çocukların zorlanması okuma kazanımı ve sesbilgisi ile ilgili farkındalık arasında önemli bir ilişkinin varlığını göstermektedir. Ancak verilen sesle başlayan sözcük bulmanın daha erken yaşlarda yapılabilmesi, bu becerinin bilişsel ve dilbilimsel etmenlerle ilişkili olduğunu düşündürtmektedir. Basit ve kısa hece yapıları Türkçede algılama kolaylığı sağlamaktadır. Bu özelliğin heceyi fark etmede olduğu kadar heceyi oluşturan seslerin, özellikle baştaki sesin fark edilmesini kolaylaştırdığı verilen sesle başlayan sözcük bulmanın okul öncesi yaşlarda başarılabilmesinden anlaşılmaktadır.

Okulöncesi dönemde sesbilgisi ile ilgili üstdil işlemlerinin vurgulanmasının sesbirim farkındalığı ve sesbirimlerin görsel simgeleri, yazı birim farkındalığının kazanılmasını destekleyeceği ve okuma/yazma olgusunu hızlandıracağı anlaşılmaktadır"14. Ancak ilk okuma yazma öğrenirken sesin hecenin sonunda olduğu pozisyonu çözümlemek doğru seslendirme açısından gerekli bir beceridir.

Çocukların sesleri edinimi kadar sesbilgisi ile ilgili işlemleri edinimi de önemlidir. Araştırmalar dizisel işlemler (önleștirme, art-damaksıllaşma, duraklaştırma, sürtünmelilerin kayması, akıcıların farklılaştırılması

\footnotetext{
${ }^{12}$ C.J. Lonigan, vd, "Development of emergent literacy and early reading skills in preschool children: evidence from a latent-variable longitudinal study",

Development Psychology, 2000, 36 (5), pp. 596-613.

${ }^{13}$ Sema Karakelle, "Fonolojik Farkındalık ve Harf Bilgisinin İlk Okuma Becerisi Üzerindeki Etkisi", İstanbul Üniversitesi Psikoloji Çalışmaları Dergisi, 2004, 24, Ss. $45-56$.

${ }^{14}$ Funda Acarlar vd. "Türk Çocuklarında Üst Dil Becerilerinin Gelişimi ve Okuma ile İlişkisi", Türk Psikoloji Dergisi, 2002, 17(50), s. 71.
}

Sayfa/Page | 75

İGÜSBD

Cilt: 1 Sayı: 2

Ekim /

October 2014 
Sayfa/Page | 76

İGÜSBD

Cilt: 1 Sayı: 2 October 2014

işlemlerinde) ve dizimsel basitleştirme işlemleri bakımından (seslem yitimi ve tekrarlama, ünsüz düşürülmesi, ünlüleşme, ses aktarımı, benzeşim işlemleri, bağlam duyarlı-ötümlüleşme-ötümsüzleşme) çocuklarda gelişimsel farklılık olup olmadığı sorununa da odaklanmıştır. 5;0-8;0 yaşlarındaki çocukların sesbilgisi ile ilgili işlemleri ediniminde "Dizimsel işlemler açısından bakıldığında yaş ve cinsiyet açısından bir farklılık saptanmıştır. Dizisel basitleştirme işlemleri açısından bakıldığında ise yaş açısından bir farklılık olduğu belirlenmiştir"15. Örneğin k-t, g-d gibi önleştirme ve l-r gibi akıcıların farklılaştırılması veya $\mathrm{f}, \mathrm{v}, \mathrm{s}, \mathrm{z}$, ş, j yerine $\mathrm{t}, \mathrm{d}$, p, b gibi durak sesi üretme işlemleri yaşa bağlı olarak gelişmektedir. Ünsüzlerin yumuşaması yani ötümlüleşmesi hadisesi de (p, ç, t, k yerine b, c, d, g) yaşa bağlı gelişen işlemlerdir. Sesbilgisi ile ilgili işlemleme becerisinin sekiz yaşlarına kadar gelişmesi ilk okuma yazma etkinliklerinde de bu becerinin geliştirilmesine önem verilmesi gerektiği sonucunu ortaya çıkarmaktadır.

İlk okuma yazmaya hazırlık döneminde çocuklar sözcüklerin başında bulunan sesleri kolaylıkla ayırt edebilmekte ve tanımaktadırlar, denilebilir. Sesin sözcügün sonunda ve ortasında yer aldığı durumlarda sesi tanıma, ayırt etme ve fark etme olgusunun ilk okuma-yazma ile beraber geliștiği anlaşılmaktadır. Sözcük tanıma ile hece tanıma birbirine karıştırılmamalıdır. Çünkü bu çalışmalar farklılıkları ve benzerlikleri ayırt etmeyi ve birleştirmeyi gerektirir. Birinci sınıf öğrencilerinin fonolojik farkındalık düzeyleri ve ilk okuma yazmanın başlangıç aşamasındaki becerileri arasında da bir ilişki olduğu ifade edilmektedir. "Fonolojik farkındalık becerisinin birinci dönemin ortasında elde edilen yazma başarıları üzerinde önemli bir rol oynadığı; ancak ikinci dönem yazma başarıları üzerinde önemli rol oynamadığı sonucuna ulaşılmıştır"16. Yangın (2009) ${ }^{17}$ tarafından yapılan bir başka araştırmada ise okula hazır oluş değişkeninin yazma performansı üzerinde yordayıcı olduğu; harf-ses ilişkisi ve ses farkındalığı değişkeninin ise yazma becerisi üzerinde önemli birer yordayıcı olmadıkları bulguları elde edilmiştir. Dikkat edilecek olursa sesbilgisel farkındalık ilk okuma yazmanın ilerleyen aşamalarında çocukların dil becerileri üzerinde belirleyici ve etkileyici bir etmen değildir. Çünkü okuma yazmayı öğrenen çocuk, çocuk analizini başarmış demektir.

15 Seyhun Topbaş vd., "Gaziantep İlinde Yaşayan 5:0-8:0 Yaş Çocuklarının Dil Gelişimlerinde Sesbilgisel İşlemlerin İncelenmesi”, 2. Ulusal Dil ve Konuşma Bozuklukları Kongresi Bildirileri, Kök Yayıncılık, Ankara, 2005, ss. 141-149. 16 Özge Erdoğan, İlköğretim Birinci Sınıf Öğrencilerinin Fonolojik Farkındalık Becerileri ile Okuma ve Yazma Becerileri Arasındaki İlişki, Basılmamış Yüksek Lisans Tezi, Hacettepe Üniversitesi Sosyal Bilimler Enstitüsü, Ankara, 2009, s. IV. 17 Banu Yangın, "Hazırbulunuşluk ile İlk Okuma ve Yazma Başarımları Arası İlişki", Hacettepe Üniversitesi Eğitim Fakültesi Dergisi. 2009, 36, ss. 316-326. 
Sesbilgisel farkındalık konusundaki araştırmaların bilişsel boyutları da dikkatte alması gerekmektedir. "Dilin işlenmesi, bilgiyi işleme ve depolamanın önemli bir unsurudur. İnsan dilinin gelişimi, bilişte temel olan bir çeşit soyutlamayı temsil eder"18. Ancak biliş ile ilgili işlemlemeler ve süreçlerle bilme içerikleri birbirinden farklıdır. Türkçede her harfin bir sese karşılık gelmesi çocukların sesleri algılamasını kolaylaştırmaktadır. İlk okuma ve yazmada sesin başta, ortada ve sonda verildiği durumlarda çocukların okuma ve yazmada zorlandıkları söylenebilir. Harf-ses bağlantıları konularında öğretmenler farklılıkları ve benzerlikleri kavratacak eylem ve etkinlikler düzenlemelidirler. Baydık'ın (2002) ${ }^{19}$ "Okuma Güçlüğü Olan ve Olmayan Çocukların Sözcük Okuma Becerileri" başlıklı araştırmasında, okuma güçlügü olan Türk çocuklarının sesbilgisel okumayı başaramadıkları için okuma-yazmaya geçemedikleri sonucuna ulaşılmıştır.

Çocuklar Türkçenin ses-harf yapısını kavrayamadıklarında, ses çözümlemesini yapamadıklarında ilk okuma yazma öğrenmekte zorlanmaktadırlar. Kesikçi ve Amado (2005) yaptıkları bir araştırmada ise, çocukların fonolojik yazılı bellekleri ile fonolojik sözel belleklerini karşılaştırmaya çalışmışlardır. Çocukların fonolojik sözel bellek türünde daha fazla hata yaptıkları görülmüştür. "Bu da bize okuma güçlügü sorunu olan çocukların fonemlerin(sesbirimlerin) harflere dönüştürülmesinde normal çocuklara oranla daha fazla güçlük yaşadığını göstermektedi"20. "İlk Okuma Yazma Öğretimi”nde çocukların zorlandıkları sesbilgisi işlemleri göz önüne alınmak zorundadır. Özellikle okuma güçlüğü çeken çocukların ses analizlerini doğru yapamamalarının yanı sıra sesleri bellekte kodlamakta da zorlanacakları bir gerçektir.

"Çocuk, sınırlı sayıda ses birimlerini birbirine eklemleyerek, ses zincirleri ve anlamlı birimler oluşturur. Çünkü ses birimlerinin grupları, sesin; vurgulu-vurgusuz, uzun-kısa, yüksek-alçak, tiz-pes zıtlıkları dilin anlam alanında karşıtlıklar ortaya çıkararak anlamının oluşmasını sağlamaktadır. Ses birimleri; sesli-sesli, sessiz-sesli, sürekli-süreksiz, girtlak sesleri-gırtlaktan olmayan sesler, keskin-boğuk, ötüşümlüötüşümsüz, genizli-genizsiz, yoğun-pes-tiz, bemolleşmiş-bemolleşmemiş, diyezleşmiş-diyezleşmemiş, gergin-gevşek özelliklerine göre hakkı

18 R. Solso vd., Bilişsel Psikoloji, çev. Ayşe Ayçiçeği Dinn, Kitabevi Yayınları, İstanbul, 2007, s. 382.

19 Berrin Baydık, Okuma Güçlüğü Olan ve Olmayan Çocukların Sözcük Okuma Becerilerinin Karşılaştırılması, Basılmamış Doktora Tezi, Ankara Üniversitesi Eğitim Bilimleri Enstitüsü, Ankara, 2002.

${ }^{20}$ Hande Kesikçi ve Sonia Amado, "Okuma Güçlüğü Olan Çocukların Fonolojik Bellek, Kısa Süreli Bellek ve WISC-R Testi Puanlarına Ait Bir İnceleme”, Türk

Psikoloji Dergisi, 2005, 20(55), s. 106.

Sayfa/Page | 77

İGÜSBD

Cilt: 1 Sayı: 2

Ekim /

October 2014 
Sayfa/Page | 78

İGÜSBD Cilt: 1 Sayı: 2 Octoberim /

verilerek seslendirilmesi gerekir.... Cümlelerin seslendirilmesinde bazı heceler üzerinde alçalma veya yükselmelerin olması, dil kurallarının çıkarılan seslere baskısı sebebiyledir. Seslerin perde aralarındaki aralıkları sezmek, akıcı ve anlamlı okuma için de gereklidir. Günlük konuşmalarda her türlü ses tonu kullanılırken, okumadaki telaffuz davranışları bazı ses tonlarına izin vermez. Sesin ahenk ölçülerinin değişmemesi, ses aralıklarının dilin izin verdiği ölçüde çıkarılması vb. ilkeleri çocuk, tecrübeleriyle öğrenecektir. Kısa heceleri kısa, uzun heceleri de uzun çıkararak, ses iniş-çıkışlarındaki tiz veya pes sesleri ayırt ederek, sesleri birbirine karıștırmamayı da öğrenecektir"21. İlk okuma yazmada ses birimlerine dikkat edilerek seslendirmelerin yapılması okuma ve yazma öğrenmeyi destekleyici bir etkinlik olacaktır. Parçalar üstü dil birimlerinin doğru oluşturulması da ilk okuma yazmada ses-anlam ilişkisinin doğru kurulabilmesinde etkilidir.

İlk okuma ve yazmada çocukların sesleri karıştırmalarında sesin yapısından kaynaklanan özelliklerin etkili olup olmadığı da pek araştııılmış değildir. "Sonuçta sesleri tanımayla okuma ve yazmanın öğrenildiği anlaşılmaktadır. Dikkat edilirse hatalar çoğunlukla kelime birimleri arasındadır. Bu durumda ilk okuma yazma öğrenmede hem görme hem ses hem anlam ilişkisinin gerekli olduğu anlaşılmaktadır" 22 . Bu sebeple ilk okuma yazmada sadece harflerin yazım kolaylığı ve seslerin edinim sıraları esas alınarak öğrenme yaklaşımları geliştirmek yeterli değildir. Harf-sesanlam ilişkisini göz önüne alacak öğrenme yaklaşımlarına ihtiyaç vardır.

"Öğrencilerin konuştuğu dil; vurgu, ezgi vb. özellikler bakımından tutumlu bir şekilde kullanılmaktadır. Çocuklar konuşurken sesleri kolay çıkarma, farklı sesleri birbirine yaklaştırma ya da eş sesler çıkarma davranışlarıyla, kelimeleri az çaba ile söyleme eğilimindedirler. $\mathrm{Bu}$ bakımdan birinci sınıfta harf, hece, kelime ve cümlelerin öğretiminde ses uyumları; sessizlerin kök, gövde, ek ilişkileri; sert sessizlerle yumuşak sessizler arasındaki farklar, ses benzeşmeleri, (y) sessizinin söylenişi, ( $\breve{g}$ ) nin söylenişi, ö ve o'dan sonra gelen ( $\breve{g}$ ) önem taşır. İmlâ kurallarına uygun bir konuşmada dilin kullanılması, konuşma dili seslerinin öğrenciler tarafından hem konuşma hem yazma için mesaj olarak algılanmasında etkilidir"23.

${ }^{21}$ Ferah, a.g.e., 2001, s. 28.

22 Aysel Ferah, İlk Okuma ve Yazma Öğrenmede Görsel Algı ve Zekânın Yeri, Basılmamış Yüksek Lisans Tezi, Marmara Üniversitesi Sosyal Bilimler Enstitüsü, İstanbul, 1996, s. 128.

${ }^{23}$ Ferah, a.g.e., 2001, s. 29. 
"Semantik bellek; gerçekler, kavramlar, kelimeler, tanımlar ve gramer kurallarıyla ilgili bilgileri kapsayan bir uzun süreli bellek türüdür. Sınıfta öğrendiklerimizin çoğunluğu semantik belleğe aktarılır. (Schacter et al. 2000)"24. Çocuklar ilk okuma yazma öğrenirken harf-ses, hece, kelime vb. dil birimlerine ait bilgileri semantik bellekte kodlarlar. Bu kodlama da hatalar da ortaya çıkmaktadır. Çocukların temel zorlukları seslerin öbekler içindeki kullanımlarıdır. Örneğin "portakal" sözcüğünü "porkatal" biçiminde söyleyen bir çocuk, ses hataları yapıyor demektir. Bu örnekte özellikle hece aktarımı veya hece karıştırma olgusundan söz edilebilir. Yine "koş" yerine "goş" diyen bir çocuğun duraksılaştırma problemi yaşadığı anlaşılmaktadır. Bu gelişimin uzun yıllar devam ettiği söylenebilir. Çocukların ilk okuma yazmayı öğrendikten sonra çevrede konuştukları gibi yazma eğiliminde oldukları göz önüne alınacak olursa bu söyleyiş hataları aynı zamanda yazım hatası olarak da karşımıza çıkacaktır. Türkçe bir sesi doğru çıkardığından emin olan bir çocuk veya bir sözcüğü doğru söylediğine inanan bir çocuk, o ses veya sözcük ile ilgili bir kavram çerçevesi oluşturur. Onlar hakkında yeni bir şey duymadan ses veya sözcüklerin tekrarı ile yetinir.

Çocukların ses perdeleri, hece uzunlukları-kısalıkları, tonlamaları ile ilgili gelişimleri de ilk okuma yazma dönemi için önemli bir değişkendir. "Dilimizin ahengi, her tür sesin birbirine karışmasına, bunların ilişkilerinin kurulmasına, birbirlerini takip ettikleri aralıklara imkân veren bir dildir. Bu sebeple seslerin birbirleriyle karışımı, ilişkileri ve aralıklarına ait ilkelere saygı gösterme konusunda öğretmen titiz davrandığında, çocuklar da titiz davranacaklardır"25. Türkçe ilk okuma yazmada hem çocuklardaki ses edinimi hem Türkçe seslerin kullanım, söyleyiş-söyleniş sıklıkları hem de harflerin yazım kolaylıkları göz önüne alınarak yapılacak bir öğretimin önemi kendiliğinden anlaşılabilir.

Araştırmalar, okuma öğrenmenin üç farklı beyin bölgesinin (sol alt frontal girus, sol parietotemporal bölge vd.) kullanılmasını gerektiğini vurgulamaktadır. “Gorman'a göre (2003), okuma öğrenmek için ilk adım fonem üretme, ikinci adım kelime analizi, üçüncü adım ise otomatik belirleyici olarak ifade edilmektedir. Bu üç işlem beynin üç ayrı bölgesinde gerçekleşmektedir. Örneğin fonem üretme aşamasında seslendirme işlemi her kelimenin harflerini fonem denilen temel seslere dönüștürmeyi (k-e-di) gerektirir. Kelime analizi; bir kelimenin harflerini tek tek seslendirdikten sonra kelimenin hecelerine ayrıştırılması veya hecelerin uygun seslerle

${ }^{24}$ Rod Plotnik, Psikolojiye Giriş, çev. Tamer Geniş, Kaknüs Yayınları, İstanbul, 2009, s. 246.

${ }^{25}$ Aysel Ferah, Türkçe İlk Okuma ve Yazmayı Öğrenme, Türkçe Okuyup Yazmak İçin, Ankara: Nobel Yayınları, 2007, s. 78.

Sayfa/Page | 79

İGÜSBD

Cilt: 1 Sayı: 2

Ekim /

October 2014 
Sayfa/Page | 80

eşleştirilmesidir. Okumayı öğrenmeye aşamasında çocukların özellikle fonem üretme ve kelime analizcisini kullandıkları belirtilmektedir. Son olarak alıştırmalarla okuma işlemi otomatikleşir ve kalıcı bir kelime dosyası gelişerek çocuk kelimeyi gördüğü anda tanıyabilir"26. Bu sebeple ilk okuma yazmada gramer yapıların biliş ile işlemlenmesine önem verilmelidir.

"Türk alfabesindeki işaretlerin ses değerlerinin ilk okuma yazma esnasında doğru öğretilmesi, sözcüklerin bu ses biçimleriyle oluşturulduğu gerçeğinin unutulmaması gerekir. Ses değerlerini doğru bir şekilde çıkarmayı öğrenme, ağız farklılıklarını da azaltıcı bir işleve sahiptir. Bu yüzden ses temelli cümle yöntemini herhangi bir ideolojik (yapılandırmacı, bilişselci, Gestalt vb.) yaklaşıma bağlamak hatalıdır. Çünkü bu yaklaşımlar, ilk okuma yazma gerçekliğinin bütünlüğünü kapsayıcı değildirler"27. İlk okuma yazma öğretiminde, hangi yöntem kullanılırsa kullanılsın, dilin temel alanlarının ve yapısal özelliklerinin dikkate alınması zorunludur. Öğrenme uygulamalarında tek bir yöntemin ilkeleri değil bütün öğrenme yaklaşımlarının verimli ve faydalı yönleri eylem ve etkinliklerde yer almalıdır. Aksi hâlde Türkçe ilk okuma yazma öğretiminde istenilen düzeyde başarı sağlamak mümkün değildir.

Unutulmamalıdır ki "Okumada harfleri tanımak çok büyük bir problemdir. Çünkü algılama harflerden çok şekil ve söz birimlerine yöneliktir"28. Özellikle benzer olan harf gruplarını ayırt etmek çocuklar için güç bir eylemdir. İlk okuma ve yazma açısından sesin sözcükte bulunduğu yer kadar harflerin grafik özelliklerinin de öğrenmelerini etkileyip etkilemeyeceği tartışılabilir. "Teşhis sırasında, hafızaya alınanların neyi temsil ettiği, geçmiş tecrübelere göre neyin işareti ya da habercisi olduğu, çocuğun ihtiyaçlarına göre ne anlama geldiğine bağlıdır. Çocuğun algı malzemesi üzerinde yaptığı bu zihni etkinliğe, soyutlamaya ve kavramlaştırmaya düşünce adı verilebilir"29. Bu öğretimde, harflerin kolay yazılmaları kadar çocuklarda seslerin gelişimi konuları da dikkate alınarak harf-ses eşleştirilmesinin kurallarını kavratıcı bir öğrenme modeli geliştirilmelidir.

26 Plotnik, a.g.e., s.320.

${ }^{27}$ Aysel Ferah, "Türkçe İlk Okuma ve Yazma Göstergelerinin İrdelenmesi", Türk Dili Dil ve Edebiyat Dergisi, 2009, 688, s. 360.

${ }^{28}$ Ali Osman Özcan, "İlk Okuma Yazma Öğretiminde Rol Oynayan Psikolojik Faktörler", Hacettepe Üniversitesi II. Eğitim Bilimleri Sempozyumu Bildirileri, Ankara, 1995, s. 5.

${ }^{29}$ Ali Osman Özcan, "ìlk Okuma Yazma ve Hafıza", Bilgi ve Toplum Dergisi, 2, 1999, s.202. 
İlk okuma yazma öğretimi ile ilgili çalışmalarda çocukların Türkçe sesbilgisi gelişimleri araştırmaları göz ardı edilmemelidir. İlk okuma yazma alanındaki eserlerde ilk okuma yazma gerçekliği ele alınmalı, ilk okuma yazma sonrası düzeyler ise Türkçe öğretimi içinde değerlendirilmelidir. Yabancı dillerdeki araştırmalar Türkçe ilk okuma yazma alanını açıklama, anlama ve yapılandırma için değil sadece yabancı dillerle karşılaştırma amacıyla kullanılabilir. Türkçe ilk okuma yazmanın kendine özgü sorunları olduğu gerçeği görülmeden "İlk okuma ve yazma her yerde aynıdır; aynı konu, içerik, yöntem ve amaçları vardır." diye düşünmek bilimsel tutuma terstir. Bu tür yaklaşım yüzünden ilk okuma yazma alanı bazen eğitim bilimleri bazen okuma-yazma bilenler için olan Türkçe öğretimi alanı içine alınmıştır. Oysa Türkçe ilk okuma yazma alanı bağımsız bir disiplin olarak bilim programlarında yerini alacak kadar geniş, derin ve kapsamlı bir alandir.

\section{Sonuç}

İlk okuma yazma öğrenmeye başlayan çocukların büyük çoğunluğunun sözel bağlamda sesleri ayırt edebildiği araştırmalarla ortaya konulmuştur. Ancak okuma güçlüğü yaşayan çocukların ses farkındalığının da diğer çocuklardan düşük olduğu yine araştırmalarda belirtilmektedir. $\mathrm{Bu}$ durumda sesleri ayırt etmeye yönelik ilk okuma yazma öğretimi yöntemlerinin özellikle okuma güçlüğü çeken çocuklar için daha yararlı olacağı söylenebilir. Okuma-yazma ilişkileri bakımından "ses" konusu değerlendirilecek olursa; okunan bir metinden anlam çıkarabilmenin ton, vurgu, ezgi gibi dilin sese dayalı müzikal yönüyle ilişkili olduğu söylenebilir. İlk okuma yazma hangi yöntemle öğretilirse öğretilsin, okunan metnin ses değerlerinin hakkının verilerek seslendirilmesi, çocukların sesli okuduğunu-dinlediğini anlama başarısını etkileyecektir.

Çocukların erken edindikleri seslerle ilgili yapılan çalışmalarda " $k, t$, $m, p, b, c ̧, c$ " seslerinin en erken edinilen sesler olduğu ve bu seslerin öğrenilmelerinin dildeki ses kullanım sıklığıyla da ilişkili olduğu belirtilmektedir. $\quad \mathrm{Bu}$ seslerin söyleyiş kolaylığı bakımından öncelik taşıdıkları anlaşılmaktadır. Türkçe ilk okuma yazma öğretiminde seslerin öğretim gruplarına bakıldığında "l, t, n, r, m" seslerinin-harflerinin öncelikli olarak öğretilmesi çocukların sesleri edinimi bulgularıla örtüşmemektedir. Oysa ilk okuma yazma öğretimine çocukların erken edindikleri ve kolay seslendirdikleri seslerle başlansa öğretim süreci daha da verimli hale gelebilir. Özellikle " $r$ " sesinin en geç edinilen ses olması dikkat çekici bir sonuçtur. Türkçe ilk okuma yazma öğretiminde ise "r" sesi ikinci ses grubunda öğretilmektedir. Bu durum çocukların sesleri edinimi ile ilgili bulgularla çelişmektedir. Yukarıda belirtilen çocukların ses gelişim

Sayfa/Page | 81

İGÜSBD

Cilt: 1 Sayı: 2

Ekim /

October 2014 
Sayfa/Page | 82

İGÜSBD Cilt: 1 Sayı: 2 October 201

özellikleri ilk okuma yazma öğretim yöntemleri geliștirilirken yol gösterici niteliktedir.

İlk okuma yazma öğretimi içerikleri belirlenirken sadece seslerin çıkarılış kolaylıkları ya da sadece harflerin yazım kolaylıklarının temel alınması tartışılabilir bir konudur. Çocukların büyük çoğunluğunun ilk okuma yazmaya başlarken ses çözümlemesi yapabildikleri ve harfleri çizebilecek görsel motor olgunlukta oldukları göz önüne alınacak olursa, ilk okuma yazmadaki esas sorunun harf ve seslerin zihindeki eșleștirilmesi ve bunların birbirine örtüştürülmesi sorunu olduğu da anlaşılabilir. Seslendirme işlemi güzel ve doğru konuşma, okuma-anlama için gereklidir. Ancak seslerin çıkarılış kolaylığı, ses kullanım sıklığıyla ilişkili olduğundan dilde sık kullanılan sözcüklerin bellekte kalıcı olması ve kolay hatırlanabilmesi sebebiyle öğretim içeriklerinde öncelikli olarak yer verilmelerinin kolay ve kalıcı bir öğrenme açısından yararlı olacağı düşünülebilir. İşleyen bellek ve uzun süreli bellek ağlarından geri getirilmeleri de kolaylaşır. İlk okuma yazmaya yeni başlayanlar işleyen belleklerini etkinleștirdikleri halde uzun süreli bellekte etkinlik olmadı̆̆ durumlarda hatırlamaları zorlaşır ve öğrendiklerini de çabucak unuturlar. Çocuklar bilgiyi belleğe alma kurallarını öğrendiklerinde daha başarılı olurlar.

Türkçe ilk okuma yazma öğrenme alanında sesbilim deneyleri de yapılmalıdır. "Çağdaş dilbilimde fonetik deneylere daha geniş yer verilmektedir. Deneysiz yapılan fonetik(sesbilim) incelemeler önemsiz ve anlamsız kabul edilir" ${ }^{30}$. Ancak fonetik deneylerinin Türkçe esas alınarak yapılması doğru sonuçlar verebilir. Altı-yedi yaşlarındaki çocukların Türkçe hece, kelime ve cümlelerde sesleri, tonlamaları, vurguları, renklendirmeleri uygularken hangi aşamalarda zorlandıkları ile ilgili araştırmalar bulunmamaktadır. Çocuk sesi ile yetişkin sesinin işlemlenmesindeki farklılıklar araştırılmalıdır. İlk okuma ve yazma öğretiminde de çocuk sesinin geliştirilmesi esas alınmalıdır.

Çocukların dil öğrenirken kullandıkları zihinsel işlemleme yapma biçimleri birbirinden farklıdır. Bazı işlevleri gerçekleştirirken yapılan zihinsel işlemlemeler, sözcüklerin ve cümlelerin bir öncekini takip etmelerini gerektirir. Bu işlemlemeleri yapabilme becerilerini öğrenme bakımından gelişimsel bir sıra ve düzenin olması gereği de açıktır. İlk okuma-yazmadaki harflerin öğrenme sırasına bağlı olarak yapılan eylem ve etkinlikler, çocuğa görelik ilkesine uygun olarak düzenlenmelidir.

${ }^{30}$ Afad Qurbanov, Ümumi Dilçilik, Qrifli Neşir, Bakü, 2004, s. 472. 


\section{KAYNAKÇA}

ACARLAR, Funda. vd. (2002). Türk Çocuklarında Üst Dil Becerilerinin Gelişimi ve Okuma ile İlişkisi, Türk Psikoloji Dergisi, 17(50), 63-73.

BAYDIK, Berrin (2002). Okuma Güçlüğü Olan ve Olmayan Çocukların Sözcük Okuma Becerilerinin Karşılaştırılması, Basılmamış Doktora Tezi, Ankara: Ankara Üniversitesi Eğitim Bilimleri Enstitüsü.

ÇELENK, Süleyman. (2008). İlköğretim Okulları Birinci Sınıf Öğrencilerinin İlk Okuma ve Yazma Öğretimine Hazırlık Düzeyleri, Abant İzzet Baysal Üniversitesi Eğitim Fakültesi Dergisi, 8(1), 83-91.

ÇİMEN, Canan.; AKLEYLEK, Sedat; AKYILDIZ, Ersan. (2008). Sifrelerin Matematiği: Kriptografi. Ankara: ODTÜ Yayıncılık.

DURGUNOĞLU, Aydın Y. ve ÖNEY, Banu. (2000). Literacy development in two languages: cognitive and sociocultural dimensions of cross-language transfer. In Editör Proceedings of the A Research Symposium on High Standards in Reading for Students From Diverse Language Groups (78-99).

EGE, Pınar. (2005), Türkçede Fonemlerin Edinimi, 2. Ulusal Dil ve Konuşma Bozuklukları Kongresi Bildirileri. Ankara: Kök Yayıncılık.

ERDOĞAN, Özge. (2009). İlköğretim Birinci Sınıf Öğrencilerinin Fonolojik Farkındalık Becerileri ile Okuma ve Yazma Becerileri Arasındaki İlişki, Basılmamış Yüksek Lisans Tezi. Ankara: Hacettepe Üniversitesi Sosyal Bilimler Enstitüsü

FERAH, Aysel. (1996). İlk Okuma ve Yazma Öğrenmede Görsel Algı ve Zekânın Yeri, Basılmamış Yüksek Lisans Tezi. İstanbul: Marmara Üniversitesi Sosyal Bilimler Enstitüsü.

FERAH, Aysel. (2001). İlk Okuma-Yazmada Ses Algısı, Çağdaş Eğitim Dergisi, 280: 27-34.

FERAH, Aysel. (2007). Türkçe İlk Okuma ve Yazmayı Öğrenme, Türkçe Okuyup Yazmak İçin, Ankara: Nobel Yayınları.

FERAH, Aysel. (2009). Türkçe İlk Okuma ve Yazma Göstergelerinin İrdelenmesi. Türk Dili Dil ve Edebiyat Dergisi, 688, 348-363. 
Sayfa/Page | 84

İGÜSBD Cilt: 1 Sayı: 2 October 2014

FERAH, Aysel. (2011). 2005 Türkçe Öğretim Programı ve Ses Temelli Cümle Yönteminin Ses Sıklığı ve Hece Oluşturma Açısından İncelenmesi. Çağdaş Ĕ̆itim Dergisi, 36, (383): 34-41.

GÜL, G. (2006). Hafif Derecede Zihinsel Engelli Çocukların Okuma Becerilerine Ses Bilgisel Farkındalık Becerileri Eğitiminin Etkisinin İncelenmesi, Basılmamış Yüksek Lisans Tezi. Ankara: Hacettepe Üniversitesi Sağlık Bilimleri Enstitüsü Özel Eğitim Bilim Dalı.

KARAKELLE, Sema. (2004). Fonolojik Farkındalık ve Harf Bilgisinin İlk Okuma Becerisi Üzerindeki Etkisi. İstanbul Üniversitesi Psikoloji Çalışmaları Dergisi, 24, 45-56.

KESİKÇİ, Hande ve AMADO, Sonia. (2005). Okuma Güçlüğü Olan Çocukların Fonolojik Bellek, Kısa Süreli Bellek ve WISC-R Testi Puanlarına Ait Bir İnceleme. Türk Psikoloji Dergisi, 20(55), 99-110.

KOMİSYON (2005). Türkçe Öğretim Programı. Ankara: MEB Yayınları.

LONIGAN, C. J., BURGESS, S. R., ve ANTHONY, J. L. (2000). Development of emergent literacy and early reading skills in preschool children: evidence from a latent-variable longitudinal study. Development Psychology, 36 (5), 596-613.

ÖZCAN, Ali Osman. (1995). İlk Okuma Yazma Öğretiminde Rol Oynayan Psikolojik Faktörler. Ankara: Hacettepe Üniversitesi II. Eğitim Bilimleri Sempozyumu Bildirileri.

ÖZCAN, Ali Osman. (1999). İlk Okuma Yazma ve Hafiza. Bilgi ve Toplum Dergisi, 2, 201-215.

ÖZTUNÇ, Selda (1994). Okuma Kavramları Testinin Türk Çocuklarına Uyarlanması, Basılmamış Yüksek Lisans Tezi. İstanbul: Marmara Üniversitesi Sosyal Bilimler Enstitüsü Sınıf Öğretmenliği Ana Bilim Dalı.

PLOTNIK, Rod (2009), Psikolojiye Giriş, çev. Tamer Geniş, İstanbul: Kaknüs Yayınları.

QURBANOV, Afad. (2004). Ümumi Dilçilik, Bakü: Qrifli Neşir.

SOLSO, R; MACLIN M. K. ve O. H. MACLIN(2007). Bilişsel Psikoloji. (çev: Ayșe Ayçiçeği Dinn). İstanbul: Kitabevi Yayınları. 
TEKCAN, I. A.; GÖZ I.;YALÇIN, S.; AKIRMAK, U.; SERBEST, S.; FIRAT, C. ve RODOPLU, S. (2002). Yazılı Türkçenin Kelime Sıklığı Sözlügü̈nün Geçerliği Üzerine Bir Çalışma, Türk Psikoloji Dergisi, 17 (50), 27 - 42

TOPBAȘ, Seyhun. (1992). Konuşma Sorunlarında Sesbilgisel Yaklaşım. Anadolu Üniversitesi Eğitim Fakültesi Dergisi, 5(1-2), 131-139.

TOPBAȘ, Seyhun. (1994). Dil ve Konuşma Sorunlu Çocukların Sesbilgisel Çözümleme Yöntemi ile Değerlendirilmesi ve Konuşma Örüntülerindeki Sesbilgisel Özelliklerin Betimlenmesi, Basılmamış Doktora Tezi. Eskişehir: Anadolu Üniversitesi Sosyal Bilimler Enstitüsü.

TOPBAŞ, Seyhun. vd. (2005). Gaziantep İlinde Yaşayan 5:0-8:0 Yaş Çocuklarının Dil Gelişimlerinde Sesbilgisel İşlemlerin İncelenmesi. 2. Ulusal Dil ve Konuşma Bozuklukları Kongresi Bildirileri, Ankara: Kök Yayıncılık.

TOPBAŞ, Seyhun. (2006). Türkçe Sesletim-Sesbilgisi Testi: GeçerlilikGüvenirlik ve Standardizasyon Çalışması. Türk Psikoloji Dergisi, 21(58), 3956.

YANGIN, Banu.(2009). Hazırbulunuşluk ile İlk Okuma ve Yazma Başarımları Arası İlişki. Hacettepe Üniversitesi Eğitim Fakültesi Dergisi. 36, 316-326.

\section{Summary}

Literacy instruction has been one of the mostly debated scientific fields by Turkish scholars. For years, debates of method have prevailed the discussion scheme of literacy instruction, thus the research has overwhelmingly focused on method. Three forth of graduate research and $P h D$ dissertations examine the methods of literacy instruction. However, without acknowledging the issue of what literacy acquisition actually is, finding the answers to the questions of "how, why, when and what" is not possible. Regarding literacy acquisition, firstly, the research that focuses mainly on the question of "what is literacy acquisition?" has been examined based on the consideration that those methods, named letters, sounds, words and sentences, are in fact not methods but different approaches to the issue, then, the necessity to put emphasis on the method, techniques, tactics and strategies came forth.

A thorough analysis of the acquisition process, including the smallest sections of literacy acquisition, will assist the researchers in reaching tips on 
Sayfa/Page | 86

İGÜSBD Cilt: 1 Sayı: 2 Ekim / October 2014

literacy instruction techniques and strategies. It has been a very old assumption that smallest units of literacy acquisition are sounds-symbols and syllables. However, the proposition that these units carry no meaningful message for the child was brought forth and this issue has been left out of the research for many years. Our aim is not to discuss whether these units are meaningful agents or not, but to set out their position and significance within the learning proce ss.

No matter which approach is taken as a ground for literacy instruction, firstly defining sounds', syllables' and words' frequency of occurrence is an important step when planning a curriculum for literacy instruction. Many researchers point out the fact that acknowledging the frequency of words especially constitutes a significant place in language comprehension and acquisition. This paper deals with topics of frequency of Turkish sounds and syllables, phoneme acquisition and stages of sound development in Turkish children and also attempts to evaluate their contribution to literacy acquisition.

It is a well-known fact that sound perception, recognition, recall, distinction, articulation and supra-segmental awareness in children are important aspects of literacy acquisition. It is also noted that at the beginning of literacy acquisition, normally-developing children are in a stage where they can work out the sounds (phonological awareness) from one another, however they are still developing the skills regarding the syllables, words, sound-symbol relationship and alphabetic data and it is necessary to stress out on these topics through the process of literacy acquisition.

The relationship between frequency of sounds in Turkish and those early-acquired phonemes in children is mentioned in the article, the emphasis has been put on the importance of building the reality of literacy acquisition onto those early-acquired-sounds that develop parallel to the frequency of phonemes in Turkish speaking children. Association between cognitive development of children and sound field is mentioned and cognitive processing-reporting of the sounds is evaluated in the article. Children's acquisition of sound field during literacy instruction is defined and presented for discussion. This paper also states that in the approach called sound-based literacy instruction, no consideration was given to developmental research on sound field, except for acknowledging the name of the sound. This article has a significant role of setting out the sound development norms in Turkish children. It also acts as a roadmap for Turkish textbook writers, teachers and researchers in the field by drawing attention to sound development, phoneme processing-reporting, sound characteristics in Turkish children and research in the related field. 